\title{
Editorial \\ Anticitrullinated protein/peptide antibodies and rheumatoid factors: two distinct autoantibody systems
}

\author{
Guido Valesini and Cristiano Alessandri
}

Dipartimento di Clinica e Terapia Medica, Reumatologia, Sapienza Università di Roma, V.le del Policlinico 155, 00161 Rome, Italy

Corresponding author: Guido Valesini, guido.valesini@uniroma1.it

Published: 14 September 2009

Arthritis Research \& Therapy 2009, 11:125 (doi:10.1186/ar2786)

This article is online at http://arthritis-research.com/content/11/5/125

(c) 2009 BioMed Central Ltd

See related research by Ursum et al., http://arthritis-research.com/content/11/3/R75

\begin{abstract}
In a previous issue of Arthritis Research and Therapy, Ursum and colleagues report the relative stabilities of anticitrullinated protein/ peptide antibodies (ACPAs) and IgM rheumatoid factors during the course of rheumatoid arthritis and their differential correlation with markers of the acute-phase response. These findings add to a growing body of evidence highlighting the distinct nature of these two autoantibody systems and the role of ACPAs as a diseasespecific marker of rheumatoid arthritis.
\end{abstract}

In a previous issue of Arthritis Research and Therapy, Ursum and colleagues report data showing that the anticitrullinated protein/peptide antibody (ACPA) status is significantly more stable than that of $\operatorname{lgM}$ rheumatoid factors (RFs) during the course of rheumatoid arthritis (RA) [1] - a finding that is fully consistent with previous reports [2]. They also found that the frequency of ACPA positivity is unrelated to age in RA patients and in the few ACPA-positive patients with non-RA disease, whereas RF positivity displayed age-related increases in patients with non-RA disease and it was also more closely correlated with acute-phase inflammatory markers. These findings, which are based on serological studies in over 18,000 patients attending outpatient rheumatology clinics, add to a steadily growing body of evidence highlighting the distinct natures of these two autoantibody systems.

\section{Differential accuracy in the diagnosis of RA}

ACPAs are considered the most accurate serological marker for RA [3]. ACPA seropositivity is rarely detected in non-RA patients, although it is occasionally associated with psoriatic arthritis, tuberculosis, leprosy, and autoimmune hepatitis, and its specificity for RA (over 96\% when measured with secondgeneration ELISA) [4] is clearly superior to that of RF. In contrast, IgG RF, IgA RF, or IgM RF are a frequent finding in patients with other autoimmune disorders, in those with infectious diseases (where its prevalence depends on the primary/secondary nature of the infection, as well as on its duration), and even in healthy individuals, especially those who are elderly. The sensitivity of ACPAs is less impressive (around 68\%) [4], but better results (82\%) have been reported with assays measuring anti-Sa, the subset of ACPAs directed against modified citrullinated vimentine [5]. Anti-Sa positivity also appears to be a better predictor of radiographic progression in patients with early $R A$.

\section{Anticitrullinated protein/peptide antibody role in synovial injury}

Citrullinated proteins originate in the synovium, and ACPAs are produced in the inflamed synovium by local plasma cells. ACPAs [6] and ACPA-producing B cells have both been detected in synovial fluid from RA patients. The central role of these autoantibodies in the pathogenesis of RA has been demonstrated in a mouse model [7]. More recently, ectopic lymphoid structures in the synovia of some RA patients have been shown to support ongoing production of class-switched ACPAs [8].

\section{Correlation between anticitrullinated protein/peptide antibodies and genetic determinants of RA}

The HLA-DRB1 shared epitope alleles are a major genetic risk factor for RA. Their presence is associated with ACPApositive forms of RA, and they also influence the magnitude of the ACPA response [9]. IgM RF has not been linked to any of the genetic risk factors for RA.

\section{Temporal characteristics of anticitrullinated protein/peptide antibodies and RF expression in RA}

ACPAs and RFs are both potential components of the specific autoantibody response that characterizes the pre-

ACPA = anticitrullinated protein/peptide antibody; ELISA = enzyme-linked immunosorbent assay; RA = rheumatoid arthritis; RF $=$ rheumatoid factor. 
clinical phase of RA [10], but ACPA positivity is likely to develop earlier and its presence may contribute to the subsequent appearance of RFs [11]. Later, with the onset of clinical RA, ACPA titers rise as a reflection of immune response maturation and increasing epitope dominance [12].

\section{Conclusions}

Together with the new data of the Ursum group, the findings discussed above strongly support the view that ACPAs are a disease-specific marker of RA detectable early in the preclinical phase of the disease. In contrast, IgM-RF seropositivity is generally a somewhat later event, and it is primarily a reflection of an inflammatory process that amplifies the tissue injury already underway. As Nowak and Newkirk have noted, the RF response may well be part of a normal host defense that - in this particular setting - is transformed into a threat to tissue integrity [13]. An interesting focus for future studies would be the characterization of ACPA (particularly anti-Sa) patterns in RA patients with partial responses to treatment consisting of the remission of signs and symptoms of inflammation coupled with ongoing radiographic progression.

\section{Competing interests}

The authors declare that they have no competing interests.

\section{Acknowledgement}

The present work was supported by the Fondazione Umberto Di Mario ONLUS.

\section{References}

1. Ursum J, Bos WH, van de Stadt RJ, Dijkmans BAC, van Schaardenburg D: Different properties of ACPA and IgM-RF derived from a large dataset: further evidence of two distinct autoantibody systems. A cohort study. Arthritis Res Ther 2009, 11:R75.

2. Rönnelid J, Wick MC, Lampa J, Lindblad S, Nordmark B, Klareskog L, van Vollenhoven RF: Longitudinal analysis of citrullinated protein/peptide antibodies (anti-CP) during 5 year follow up in early rheumatoid arthritis: anti-CP status predicts worse disease activity and greater radiological progression. Ann Rheum Dis 2005, 64:1744-1749.

3. Nishimura K, Sugiyama D, Kogata $Y$, Tsuji G, Nakazawa T, Kawano S, Saigo K, Morinobu A, Koshiba M, Kuntz KM, Kamae I, Kumagai S: Meta-analysis: diagnostic accuracy of anticyclicncitrullinated peptide antibody and rheumatoid factor for rheumatoid arthritis. Ann Intern Med 2007, 146:797-808.

4. Avouac J, Gossec L, Dougados M: Diagnostic and predictive value of anti cyclic citrullinated protein antibodies in rheumatoid arthritis: a systematic literature review. Ann Rheum Dis 2006, 65:845-851.

5. Vossenaar ER, Després N, Lapointe E, van der Heijden A, Lora M, Senshu T, van Venrooij WJ, Ménard HA: RA specific anti-Sa antibodies target citrullinated vimentin. Arthritis Res Ther 2004, 6:R142-R150.

6. Spadaro A, Riccieri V, Scrivo R, Alessandri C, Valesini G: Anticyclic citrullinated peptide antibody determination in the synovial fluid of patients with rheumatoid arthritis. Arthritis Rheum 2006, 55:681-682.

7. Kuhn KA, Kulik L, Tomooka B, Braschler KJ, Arend WP, Robinson WH, Holers VM: Antibodies against citrullinated proteins enhance tissue injury in experimental autoimmune arthritis. J Clin Invest 2006, 116:961-973.

8. Humby F, Bombardieri M, Manzo A, Kelly S, Blades MC, Kirkham $B$, Spencer J, Pitzalis C: Ectopic lymphoid structures support ongoing production of class-switched autoantibodies in rheumatoid synovium. PLoS Med 2009, 6:e1.
9. van der Helm-van Mil AH, Verpoort KN, Breedveld FC, Huizinga TW, Toes RE, de Vries RR: The HLA-DRB1 shared epitope alleles are primarily a risk factor for anti-cyclic citrullinated peptide antibodies and are not an independent risk factor for development of rheumatoid arthritis. Arthritis Rheum 2006, 54: 1117-1121.

10. Nielen MM, van Schaardenburg D, Reesink HW, van de Stadt RJ, van der Horst-Bruinsma IE, de Koning MH, Habibuw MR, Vandenbroucke JP, Dijkmans BA: Specific autoantibodies precede the symptoms of rheumatoid arthritis: a study of serial measurements in blood donors. Arthritis Rheum 2004, 50:380-386.

11. Li W, Wang M, Irigoyen P, Gregersen PK: Inferring causal relationships among intermediate phenotypes and biomarkers: a case study of rheumatoid arthritis. Bioinformatics 2006, 22: 1503-1507.

12. Chibnik LB, Mandl LA, Costenbader KH, Schur PH, Karlson EW: Comparison of threshold cut-points and continuous measures of anti-CCP antibodies in predicting future RA. J Rheumatol 2009, 36:706-711.

13. Nowak UM, Newkirk MM: Rheumatoid factors: good or bad for you? Int Arch Allergy Immunol 2005, 138:180-188. 